\title{
A Mathematical Learning Journey of Toddlers in a Multilingual Environment: The Case of Danesh
}

\author{
Zetra Hainul Putra \\ Department of Science Education \\ University of Copenhagen \\ Copenhagen, Denmark \\ zetra.putra@ind.ku.dk
}

\begin{abstract}
This paper aims to present how Danesh, a toddler who moved from Indonesia to Denmark at the age of one and a half years, learned rote counting in three different languages: Indonesian, English, and Danish. Her mathematical learning journey was observed from the first time she moved to Denmark until she was in a kindergarten. The findings show some factors that influence her multilingual counting abilities: watching nursery songs on YouTube, number board games and interaction with her parents, especially her mothers.
\end{abstract}

Keywords - rote counting; multilingual; mathematical learning journey; watching nursery songs; and interaction.

\section{INTRODUCTION}

Rote counting is the first numerical skills that children learn. It occurs in the toddler years in which they begin to represent numbers, mostly from one to ten. Many studies have already investigated children numerical development from rote counting to arithmetic operations [1-6]. They also study various factors influence and predict preschool and early primary mathematical achievement. One of the main factors is family supports through interactions during some activities such as playing games.

Learning mathematics, specifically counting, can be a challenge for some multilingual children. They have to produce different languages for the same numbers. For instance, a toddler who speaks Indonesian at home and English at school should know that 1 can be pronounced as satu or one. Some studies have observed children and teenagers' mathematical and also language achievement in multilingual environments [7-10]. They show a correlation between children's multilingualism and mathematical achievement, but they do not spotlight how children expand their multilingual mathematical vocabulary. Therefore, the present study examines how Danesh, an Indonesian toddler, learns the rote counting of numbers up to ten in three different languages: Indonesian, English, and Danish. The possible factors supporting her mathematical learning journey are investigated and discussed.

\section{LITERATURE REVIEWS}

\section{A. Children's early counting process and supports}

Many studies agree that toddlers start learning numbers through the rote counting $[1-6,11,12]$. It is known as a basic counting skill for children that they memorise the sequence of numbers. This skill is developed since they learn to speak, around the age of two years [1,11]. Children can do it before they are able to write notations of those numbers [12]. In addition, at the ages 2 and 3, they learn to count objects correctly from 1 to 10 , and some of them are able to do one to one counting objects $[1,13]$. This knowledge is a foundation for children to a further development of their arithmetic skills such as combinations that make ten $[14,15]$.

Children's early counting skills develop from some stimuli. Two of them are verbal and visual stimuli. The verbal stimulus is related to an interaction between parents and children. Some studies show that parents, especially mothers, facilitate the development of children's early counting abilities [2,5]. Moreover, the parents mostly use visual representations to support their children. For example, playing number board games supports 5-year-old children's early mathematical development [4]. These games improve children's performance on the number line estimation task. In addition, videos are also main factors that influence children's mathematical development. Most children give positive responses when they engage in the activities involving information and computer technology (ICT) [16].

\section{B. Children's multilingualism}

There are some studies on children's multilingualism and their mathematical learning or achievement [8-10]. Dahm and De Angelis [8] find a positive role of mother tongue literacy in language learning as well as mathematical learning. They argue that multilingual children develop vocabulary in several languages concurrently, and at the same time, they also develop the necessary skills to pronounce difference languages when communicating with other children and adults [8]. It is a challenge for children to identify what language should they use and in which context.

Learning mathematics, such as counting, is another challenge for children. The children need to synchronise 
different vocabulary that represents a similar number. Meanwhile, children's better linguistic skills can improve arithmetic development. This can be done via counting sequence knowledge [9]. In this study, the researcher investigates a toddler's rote counting abilities in the multilingualism, Indonesian, English, and Danish.

\section{Methodology}

The present study uses a case study method mostly through a narrative form [17]. The researcher chooses this method because of its capacity to deeply observe a case within its reallife situation [18]. The data were collected from a longitudinal study that the researcher observed since the toddler, Danesh, moved to Copenhagen, Denmark, from April 2016 at age one and half years until she was going to the kindergarten in September 2017. Danesh is an only child of young couple. Her father is a postgraduate student on didactics of mathematics at one university in Copenhagen and has a role as a researcher in this study. Her mother is a medical doctor from Indonesia but chooses not to work while in Copenhagen. Both of her parents are Indonesian, but they can speak English well and understand basic Danish.

The data consist of observation of Danesh's activities at home: watching videos on YouTube and playing blocks and clock puzzles with her parents, especially her mother, unstructured interviews with her mother about her rote counting abilities in the end of December 2017, and selfreflection from her father, the researcher. The researcher focuses the observation in the moment of Danesh's rote counting activities using Indonesian, English and Danish. How numbers 1 to 10 are uttered in three different languages are shown in table 1 .

TABLE I. Numbers 1 to 10 are uttered in three different languages.

\begin{tabular}{|c|c|c|c|}
\hline Numerical & English & Indonesian & Danish \\
\hline 1 & One & Satu & En \\
\hline 2 & Two & Dua & To \\
\hline 3 & Three & Tiga & Fire \\
\hline 4 & Four & Empat & Fem \\
\hline 5 & Five & Lima & Seks \\
\hline 6 & Six & Enam & Syv \\
\hline 7 & Seven & Tujuh & Otten \\
\hline 8 & Eight & Delapan & Ti \\
\hline 9 & Nine & Sembilan & Sepuluh \\
\hline 10 & Ten & & \\
\hline
\end{tabular}

\section{FINDINGS}

Danesh moved to Denmark with minimum rote counting abilities. Her language skills were also still very limited. She could say few words in Indonesian but not in English and Danish. When the researcher asked her mother about her rote counting abilities in Indonesian, she said that she knew nothing about numbers. For the first six months in Denmark,
Danesh and her parents lived in a house with the house owners, Indonesian-Danish old couple. Then, they moved to the apartment in the city centre in the beginning of February 2017 and went to a kindergarten in the beginning of August 2017.

Danesh mostly spent her times with her mother at home, and she often watched nursery songs in English on YouTube. The researcher often observed that she watched the nursery songs involving the rote counting up to five such as "five little ducks" and "five little monkeys jumping on the bad". Actually, these songs guide her to do the rote counting back from 5 to 1 in English. Meanwhile, she learned the rote counting from 1 to 10 in English also through watching nursery songs such as "number train 1 to 10" (Fig. 1). The researcher also observed that she also watched the nursery song "ten in a bed" that is about the rote counting back from 10 to 1 . In fact, learning the rote counting from 1 to 10 in English went smoothly for her, and she could do it when she was 2-year-olds.

Fig. 1. Number song collection from YouTube

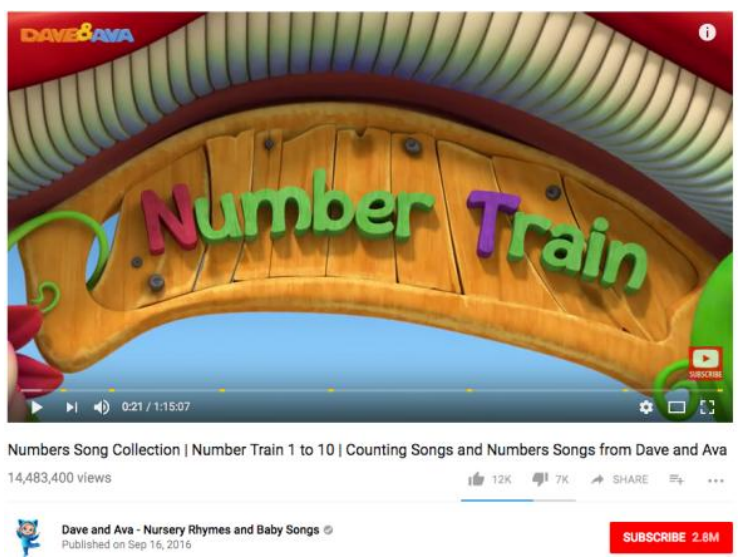

One moment around the Danesh's age of 2 years, the researcher observed the interaction between Danesh and her mother when they played with blocks. Her mother tried to help her to synchronise one block with one number. The mother pointed one block and said one, and then she followed her mother's action and also said one. Then they did this action together until they pointed the tenth block and said ten. At this time, she still found a challenge to do one to one counting objects by herself. In addition, when she played to assemble the clock puzzles consisting numbers from 1 to 12 , she still was not aware the order of these numbers.

Around the Danish's age of two and a half years, her mother was surprised when she heard Danesh uttered numbers from 1 to 10 in Indonesian. She told the researcher that it was probably because Danesh often played with the landlady, who speaks Indonesian, especially when she took Danesh from their place upstairs. She taught Danesh to utter and synchronise steps on the stair from 1 to 10 in Indonesian, namely satu, dua, tiga, empat, lima, enam, tujuh, delapan, sembilan, and sepuluh. Somehow after that, her mother supported her to do the rote counting from 1 to 10 in Indonesian. 
One day after Danesh and her parents moved to the apartment, the researcher played the clock puzzles with her. When she did not find a puzzle bearing a number that she was looking for, she asked the researcher to find it. At this time, she was already able to synchronise between symbolic numerical systems and oral representations of numbers.

In the second week of August 2017, Danesh went to the kindergarten. At this time, she started to learn Danish, and she was at school from 9 am to 14 pm from Sunday to Friday. Most of her friends at the kindergarten speak multilingualism.

At a dinner after a month of schooling, her mother told the researcher that Danesh could do the rote counting from 1 to 10 in Danish. Her mother asked her to show it to the researcher. Danesh started to say en, to, tre, fire, fem, seks, otten, $n i$, ti, by synchronising to her fingers, but she skipped counting number 7 that is syv in Danish. She tried it again, stopped for a while after seks, and waited for a help from her mother to say syv. She repeated this process for several times until she totally could do the rote counting from 1 to 10 in Danish correctly.

One day at the end of September 2017, her mother (M) asked her about what she ate at the kindergarten. The researcher recorded their interaction as follows:

M: Tadi berapa [buah] kakak makanya [di sekolah]? (Today, how many did you eat [at school]?)

M: [Spiser $d u]$ to lille brød? to lille brød? ([Do you eat] two small pieces of bread, and the correct word for small in plural in Danish is små)

D: Ja/Ya.

Her mother asked her in bilingual questions, in Indonesian and in Danish, and she answered yes that can be in Danish or in Indonesian because the pronunciation for both are similar.

In another occasion at the end of September 2017, the researcher engaged in an activity with Danesh when she sat on a sofa and played the block games. When she took the blocks one by one from a plastic back to a box on the sofa, the researcher tried to let her do one to one counting objects. First, the researcher said one when she took one block and did it until the fifth object. And then, she continued to count six to ten. After that, she took out all blocks on the sofa. The researcher changed the language into Danish by pointed one block and said en. She continued to point another object and said to, tre, until ti. Finally, the researcher provoked her to count in Indonesian by pointing one object and said satu. Danesh also followed the same action by pointing another object and said dua until sepuluh. She did not find any challenge to switch the languages from one to others when doing the rote counting.

In the end of December 2017, the researcher (R) interviewed Danesh's mother (M) to gain more information about how Danesh learns to do rote counting number from 1 to 10.

R: Would you like to tell how Danesh learns to do rote counting from 1 to 10 ? Probably from one of the three languages.
M: Long time before, [we] teach her "one, two, three" (in English), 1 until 10 in one specific language, for instance. After that [we] organise a game or an activity involving rote counting. With three repetitions, Danesh can follow it, but this should be repeated the following day. After that, she can do rote counting, as well as English and Danish.

R: So, in what language did Danesh do rote counting for the first time?

M: The first time is English and [then] Indonesian.

R: For example, counting in English, how can she do it? Is it because of watching TV/Video or communicating in English with her mother?

M: Both of them.

$\mathrm{R}:$ How is about in Indonesian?

M: Yes, that sort of thing too.

$\mathrm{R}$ : How is about counting in Danish?

M: Yes. At that time, I have not taught it yet. I waited until she was at the kindergarten to see her development. After three weeks, it seems that she could not speak Danish yet. I tested her [to count] one, two, three (in English) using Danish from 1 to 10 . It seems that she just knew 1 to 3 . I could not wait, so I taught her rote counting 1 to 10 in Danish. After that, she could have done rote counting 1 to 10 in Danish by herself. Or maybe at the school, she has been taught or heard, so when it is repeated, she still remembers it.

R: For an activity, what objects are usually used to support her rote counting abilities?

M: There are toys containing numbers one, two, three, four, and five (in English). There are also number carpets consisting numbers from 1 to 10 or 9. Usually, they are arranged or asked her where is number 1? And then she jumps to that number, where is number 2? She jumps to that number, and where is number 3 ? She jumps to that number, etc. Other than that, she plays with blocks, arranges, and then count them.

It is obvious that Danesh's mother has the main role to support the development of Danesh's rote counting abilities. Her mother combines verbal and visual stimuli to support Danesh. She provides the verbal stimuli for several times until Danesh really remembers how to say numbers 1 to 10 in three different languages. The visual stimuli, especially number boards and videos, are used intensively. These support Danesh to learn rote counting without feeling overwhelmed to learn something new. In addition, there are no different stimuli given to Danesh among learning rote counting in English, Indonesian, and Danish.

\section{DISCUSSION AND CONCLUDING REMARKS}

The purpose of the present study is to present Danesh's mathematical learning journey, specifically rote counting, in the multilingual environment: Indonesian, English, and Danish. The finding showed that Danesh developed her rote 
counting skills before she can write the notations of those numbers [12]. It is obvious that she first developed her rote counting skills in English than in Indonesian, her mother tongue. The main factor influencing her rote counting skills in English is the nursery songs. One reason is that the songs are so entertaining for children in which they can follow the actions and the utterances. So, watching videos on YouTube in the millennium era is a visual stimulus for children's counting skills development.

However, an interaction between children and parents become another important factor to support their further counting skills, synchronising between objects and oral representations. This can be seen from the engagement of Danesh's parents, especially her mother, during playing block games. At this moment, her mother tried to help Danesh to develop the meaning of her oral representations by synchronising the objects. This process can be done since children at the age of 2 -years old. In fact, this finding is consistent with other previous studies that parents and game activities support children's counting skills [1-5]. In addition, combining verbal and visual stimuli may foster toddlers to learn rote counting $[4,16]$.

When children live in a multilingual environment, people around them also support the development of their rote counting skills. Danesh, for instance, developed her rote counting skill in Indonesian from her interactions with the landlady. In this case, her parents may forget that it is important to support her counting skills in their mother tongue. It can be a challenge for her especially when she returns to Indonesia and goes to school to learn mathematics using Indonesian. In addition, Danesh learned to do the rote counting in Danish at the kindergarten, but to help her develop this skill, the parents also need to know about Danish and support her to learn at home.

In conclusion, this study exhibits that a multilingual toddler, Danesh, is challenged to learn how to do the rote counting for the same numerical symbols differently. Her counting skills are influenced by stimuli given and interactions with parents and others. This result cannot be generalised because the researcher only observes a toddler, but it gives an overview of how an early child develops her counting skills. For the further study, the researcher suggests to extend the number of multilingual children to be observed and compare more factors, such as parent education backgrounds, that can influence their counting skills.

\section{Acknowledgment}

The researcher would like to thank the Ministry of Research, Technology, and Higher Education of the Republic of Indonesia for funding this research.

\section{References}

[1] B. M. Casey, C. M. Lombardi, D. Thomson, H. N. Nguyen, M. Paz, C. A. Theriault, and E. Dearing. "Maternal support of children's early numerical concept learning predicts preschool and first-grade mathematical achievment," Child Development, vol. 00, pp. 1-18, 2016 [Online Version of Record published before inclusion in an issue].

[2] C. S. Huntsinger, P. E. Jose, and Z. Luo. "Parental facilitation of early mathematics and reading skills and knowledge through encouragement of home-based activities," Early Childhood Research Quarterly, vol. 37, pp. 1-5, April 2016.

[3] D. Leyva, C. S. Tamis-LeMonda, H. Yoshikawa, C. Jimenez-Robbins, and L. Malachowski. "Grocery games: How ethnically diverse lowincome mother support children's reading and mathematics," Early Childhood Research Quarterly, vol. 40, pp. 63-76, March 2017.

[4] J. Elofsson, S. Gustafson, J. Samuelsson, and U. Träff. "Playing number board games supports 5-year-old children's early mathematical development," The Journal of Mathematical Behavior, vol 43, pp. 134147, 2016.

[5] J. P. Benigno, and S. Ellis. " Two is greater than three: effects of older siblings on parental support of preschoolers' counting in middle-income families," Early Childhood Research Quarterly, vol. 19, pp. 4-20, 2004.

[6] J. P. McHale, and E. Fivaz-Depeursinge. "Understandidng triadic and family group interactions during infancy and toddlerhood," Clinical Child and Family Psychology Review, vol. 2, pp.107-127, 1999.

[7] D. J. Purpura, and E. E. Reid. "Mathematics and language: Individual and group differences in mathematical language skills in young chidlren”, Early Childhood Research Quarterly, vol. 36, pp.259-268, January 2016.

[8] R. Dahm, and G. De Angelis. "The role of mother tongue literacy in language learning and mathematical learning: Is there a multilingual benefit for both?", International Journal of Multilingualism, pp. 1-20, July 2017.

[9] W-J. Han. "Bilingualism and academic achievment", Child Development, vol. 83, pp. 300-321, January/Ferbruary 2012.

[10] X. Zhang, T. Koponen, P, Räsänen, K. Aunola, M-K. Lerkkanen, and JE. Nurmi. "Linguistic and spatial skills preddict early arithmetic development via counting sequence knowledge," Child Development, vol.85, pp. 1091-1107, May/June 2014.

[11] E. M. Markman. "Classes and collections: Conceptual organization and numerical abilities," Cognitive Psychology, vo. 11, pp. 395-411, 1979.

[12] E. Teubal, and J. E. Dockrell. "Children's developing numerical notations: The impact of input display, numerical size, and operational compexity," Learning and Instruction, vol. 15, pp. 257-280, 2005.

[13] B. W. Sarnecka, and C. E. Wright. "The idea of an exact number: Children's understanding of cardinality and equinumerosity," Cognitive Science, vol. 37, pp. 1493-1506, 2013.

[14] Z. H. Putra, D. Darmawijoyo, R. I. I. Putri, and J. D. Hertog. "Supporting first grade students learning number facts up to 10 using a parrot game," Journal of Mathematics Education, vol. 2, pp. 163-172, June 2011.

[15] Z. H. Putra. "Didactic contracts in realistic mathematics education teaching practices in Indonesia: A lesson on addition," in International Seminar on Education: Education Trends for Future Society, Teacher Training and Education Faculty, Muhammadiyah University of Ponorogo, August 2016.

[16] Z. H. Putra, G. Witri, and T. Yulita. "Developing elementary school learning media based on Information and Computer Technology (ICT) in integrated thematic learning of 2013-curiculum" [Pengembangan media pembelajaran sekolah dasar berbasis teknologi informasi dan komputer (TIK) pada pembelajaran tematik terpadu kurikulum 2013], Edukasi, vol. 00, pp.1-13, 2015.

[17] R. K. Yin. "Case study methods," in Handbook of complementary methods in education research, J. L. Green, G. Camilli, and P.B. Elmore, Eds. Mahwah, NJ: Lawrence Erlbaum Associates, 2006, pp. 111-122.

[18] R. K. Yin, Case study research: Design and methods. Los Angeles: Sage Publications, 2013.

[19] [Dave and Ave-Nursery Rhymes and Baby Songs]. (2016, September 16). Number song collection, number train 1 to 10, counting songs and number songs from Dave and Ava. [Video File]. Retrieved from https://www.youtube.com/watch?v=JQ-KT0cQmik 